\title{
A POSIÇÃO DA REFORMA PROTESTANTE FACE A ALGUNS PROBLEMAS DE SUA ÉPOCA.
}

A Reforma do século XVI surgiu numa época de profundas modificações. A Europa via abalar-se tôda a sua estrutura. No domínio político, o Feudalismo cedia lugar a monarquias centralizadas; no comércio, a rota para o Oriente deslocava-se do Mediterrâneo para o Atlântico, com acentuada vantagem para as nações ibéricas; geogràficamente, os horizontes se dilatavam com o descobrimento de novas terras e de novos continentes. No campo cultural as mudanças atingiam os mais variados setores, graças a influências que já vinham da Idade Média. O Renascimento é a prova concludente da mentalidade e do espírito então em voga. Velhos conceitos sôbre o universo, a vida, a sociedade, a ética, a política e a religião, todos se alteraram. A Humanidade jamais experimentara fenômeno semelhante.

A Reforma Protestante só poderá ser bem compreendida quando vista à luz dessa situação, e da qual fêz parte integrante. Ela, todavia, foi um movimento de natureza fundamentalmente religiosa, ainda que entrelaçada com outros fatôres que lhe chegam a nublar o verdadeiro sentido. Importa estabelecer a distinção e, ao mesmo tempo, correlacioná-la com os problemas que agitavam o Ocidente, sejam de ordem social, econômica, política ou de outra modalidade. Ela sofreu a influência dêles, bem como exerceu a sua. Nem é possível separar os reformadores do ambiente e da mentalidade do seu tempo.

$\mathbf{E}$ foi assim que, ao lado da Renascença, voltou a atenção para o homem, inspirada nas luzes que lhe proporcionava o redescobrimento do Evangelho, embora os dois movimentos se colocassem em posições diferentes, porque enquanto o primeiro via nêle qualidades excepcionais, a ponto de converter-se em Humanismo, o segundo liderado por Lutero, Zuínglio e Calvino, considerava-o portador de uma natureza má, pecaminosa, réu da condenação eterna, e sem possibilidade de salvar-se a não ser por um ato misericordioso de Deus; capaz de praticar o bem civil, ao alcance dos racionais, mas nunca o bem agra- 
dável a Deus, até que fôsse regenerado pela graça divina. Um ser, então, de valor muito relativo. Donde se afigura o aspecto negativo da doutrina, que, não obstante, também se reveste de importância, porque impediu a degenerescência do Humanismo em certas áreas.

E' curioso, porém, que a Reforma contribuiu de modo "suigeneris" a favor do indivíduo humano, exatamente porque viu nêle mais do que simples animal racional. Como criatura divina possui uma alma preciosa, vinda das mãos de Deus, embora arruinada, em conseqüência do pecado. Mas por isto mesmo, deve libertar-se do mal, readquirir sua primitiva condição espiritual e gozar de nôvo a comunhão com o Pai celestial. Tôdas as pessoas necessitam de salvação, mas o problema tem um cunho inteiramente individual, porque afeta em particular a cada ser humano. E' dêste modo a Reforma distingue o homem do meio social, ou melhor, do grupo, e lhe confere um valor especial, distinto. Vale pelo que é e não por causa do conjunto. A ninguém, por conseguinte, compete resolver por outro o problema das relações dêste com Deus, e de igual modo nenhuma autoridade há que possa forçá-lo a submeter-se a determinada doutrina. A consciência individual é inviolável. Cada qual tem direito à liberdade, ao livre exame, à decisão pessoal, ao estudo das Escrituras e à instrução em todos os níveis. Pelo que seria desnecessário dizer que a liberdade de consciência e de pensamento, o espírito de investigação e de crítica, bem como o ensino público, muito receberam da Reforma. E acrescente-se, outrossim, que os movimentos anabatista, sociano e arminiano, em parte frutos dela também, prestaram ainda maior contribuição, porque negando o predestinismo, anunciavam a possibilidade de salvação para todos os homens e defendiam com mais denôdo a liberdade de cada pessoa. Eles estiveram mais ao lado do homem comum do que os grandes vultos da Reforma. A guerra dos camponeses é o melhor exemplo. Identificaram-se com os mesmos, inflamaram-nos à luta e com êles se sacrificaram. Refiro-me, particularmente, aos anabatistas. Lutero ajudou os camponeses o quanto pôde, antes de deflagrada a guerra, mas quando, inopinadamente, abandonaram o alvitre que lhes propunha e pegaram em armas, mudou de atitude. Ele apelara para a fôrça do Direito, mas os revoltosos preferiram valer-se do direito da fôrça, e o resultado lhes foi terrivelmente adverso.

A rigor, então, a preocupação dos reformadores estava voltada para o indivíduo e só indiretamente para a sociedade. A 
Reforma, contudo, ao invés de isolá-lo do meio ambiente, conforme sucedia comumente na Igreja medieval, apenas o separava èticamente. Todos os fiéis, irmanados em Cristo, formavam uma só família: a comunidade dos salvos. Era, por assim dizer, uma nova sociedade, baseada na fé comum; um grupo de gente de ideais santos, de aspirações nobres, de costumes salutares. Enfim, o nôvo Israel de Deus. Estavam no mundo, mas já não pertenciam ao mundo. Precisavam, no entanto, de ainda atuar no mundo. Profissionalmente tinham que viver e agir no meio de outros, sendo em tudo e em tôda parte, verdadeiras testemunhas de Deus. O que fizessem seria para a glória de Deus.

Em virtude da sua doutrina do sacerdócio universal dos crentes, a Reforma aboliu a distinção entre clérigos e leigos, revigorando o ensino bíblico que todos são iguais perante Deus. A vida de cada cristão é santa, de sorte que cada um tem livre acesso ao divino Criador. Assim, também, nenhuma vocação é mais sagrada do que outra. Tão divina é a do pastor, como a do médico cristão, a do advogado, a do funcionário público, a do professor, a do industrial, a do operário, etc. Nenhum dêles trabalha simplesmente para o seu sustento, mas para bem servir e glorificar a Deus. Por isso dignifica a obra em que se ocupa, respeita os superiores e estima os companheiros de labor. As instituições, por sua vez, não tem um fim utilitário em si mesmas, seja a família, o Estado, a escola, ou o que quer que seja. Existem para exaltar a Deus e beneficiar aos homens. Onde tais conceitos encontraram maior permeabilidade, ali melhores foram os resultados. Entre os evangélicos, por exemplo, os crentes têm maior participação no govêrno da Igreja; introduziram também o sistema representativo no Estado, por meio de eleições; a abolição da escravatura negra encontrou nos Quakers e nos Metodistas da Inglaterra fortes defensores. Na política mencionaria o Partido Trabalhista inglês, também de inspiração evangélica. Quanto à preocupação social, acrescentaria apenas que mais e mais ela se acentua no seio do Protestantismo, chegando alguns ao cúmulo de pretender solucionar os problemas do homem através simplesmente do "Evangelho Social".

Mas não é a Reforma a culpada pelo surgimento do capitalismo? De fato ainda existem escritores que lhe atribuem essa origem e que consideram o próprio movimento como fruto de situações econômicas. Karl Marx à luz de fatôres materiais, assim pensava, e seguindo em suas trilhas, mais recentemente, 
Max Weber e Ernesto Troeltsch fizeram da Reforma a mãe do capitalismo. Com que base? Porque as nações protestantes figuram entre as mais ricas dos tempos modernos, e isto graças à faculdade de cobrar lucros vantajosos, coisa que a Igreja $\mathbf{C a}$ tólica considera pecado de usura, mas permitido por Lutero e Calvino. Será verdade? Estará certa a gênese do capitalismo? A História nos ensina algo diferente. A Igreja Católica já nos últimos séculos da Idade Média praticava tal modalidade de comércio. João Eck, teólogo católico alemão, em 1515, defendeu a legitimidade da cobrança de juros; em Liège o capitalismo era promovido pelos cônegos, grandes senhores; algumas ordens religiosas tornaram-se riquíssimas. E' preciso ir mais longe, se quisermos encontrar as raízes do capitalismo. Achamse nos séculos que precederam à Reforma. Germinou ao tempo das Cruzadas ao Oriente; desenvolveu-se paralelamente com a decadência do regime feudal, e se acelerou depois com a Renascença e com os empreendimentos comerciais do século XVI. Os reformadores protestantes viveram nesta época e dela também receberam influências. Lutero foi menos liberal do que Calvino, porque procediam de meios diferentes e diversa fôra a educação de cada um. Lutero, filho de camponeses, vivia numa pacata cidadezinha; ao passo que Calvino era filho de burgueses e residia em Genebra, cidade ativa. Mas ambos admitiam a cobrança de juros até $5 \%$, pois costumava-se exigir muito mais. Acrescentava, porém, êste último, que isso se fizesse sòmente quando não houvesse outro meio para usar o capital, sem prejuízos a ninguém e sem ofender a personalidade humana. A norma era sempre ditada pelo imperativo de servir a Deus. O cristão é mordomo dos haveres que possui, e nunca o seu dono, porque Deus é o senhor de tudo. Em São Paulo, Brasil, na segunda década do século XVII, quando as colônias da Inglaterra, na América, mal haviam iniciado sua marcha, cobrava-se $8 \%$ de juros nos empréstimos (1).

A prosperidade dos povos protestantes, baseia-se, antes de mais nada, no caráter de seus concidadãos. Homens que honram a Deus, vivem honestamente, e por isso realizam o que é correto e útil; não malbaratam o tempo e nem a saúde, e nem consomem o fruto do seu trabalho em vícios e bagatelas. Sua filosofia da vida é norteada por suas convicções religiosas, e estas alicerçadas na Bíblia.

\footnotetext{
(1). - Inventários e Testamentos, vol. VII: 188, Publicação do Arquivo do Estado.
} 
A Reforma, ao mesmo tempo que realçou os direitos individuais e criou condições para o desenvolvimento da democracia, contribuiu para fortalecer a autoridade do Estado. Mas também neste sentido os impulsos originais vinham da Idade Média. A ruína do sistema feudal redundou no enfraquecimento da nobreza e, de outro lado, no fortalecimento dos reis. Estes, assim que puderam, subtraíram-se da hegemonia papal e passaram a governar suas nações como chefes supremos, estribados na doutrina de que tal direito lhes provinha diretamente de Deus e sòmente a Êle dariam contas. Ora, Lutero e Calvino, sob a inspiração dos ensinos dos apóstolos, adotaram idêntica opinião: os reis governavam por direito divino e, por conseguinte, merecem todo respeito e obediência. Nisto residia a garantia da paz. A revolta, portanto, é inadmissível. Daí a razão porque Lutero se opôs à agitação armada, erguida pelos camponeses, e Calvino às perturbações levantadas pelo herético Serveto, em Genebra. Mas, na França e noutras partes, os seguidores de Calvino, submetidos à perseguição, resolveram resistir pelas armas, sob a alegação de que estavam desobrigados de obediência às autoridades que desrespeitavam sua fidelidade a Deus. Assim pensava Zuínglio: é lícito usar da fôrça para destituir um mau govêrno, isto é, quando não se conduz pelos retos caminhos de Deus. Lutero, no final da vida, admitiu ser justo resistir aos tiranos. E, mais uma vez, lembraríamos que os anabatistas prestaram valiosa contribuição no setor político, porque defenderam como nenhuns outros, a absoluta separação entre a Igreja e o Estado. Cada qual é soberano dentro de sua própria esfera.

Os protestantes de então, de modo geral, interessavam-se bem pouco por política, teórica ou pràticamente. Todos consideravam o Estado como coisa passageira. O ideal está no reino de Deus, o qual só virá por obra divina e quando o Senhor quiser. A vida presente é de valor secundário. O que importa é a Eternidade, o gôzo no Céu; herança ainda de concepções medievais.

A obra iniciada pela Reforma do século XVI não parou aí; prosseguirá pelos anos a dentro: Ecclesia reformata semper reformanda. Ela tem capacidade para reagir diante de cada situação nova. Hoje, por exemplo, já não se admite que o pecado afeta apenas a alma, ou só o indivíduo. O pecado prejudica o ser integral, atinge tôdas as esferas da vida e envolve a sociedade. Não basta salvar apenas os indivíduos; é preciso ao mesmo tempo atacar o mal coletivo. O Reino é para o fu- 
turo, mas para o presente também. A vida além interessa muito, mas a atual não pode ser postergada a plano secundário, porque igualmente é obra de Deus, e inclusiva no mundo que Êle criou.

O cristão é o sal da terra e a luz do mundo, e caso se exima de cumprir sua vocação, em todos os setores, dará oportunidade para que os ímpios o substituam. O ideal cristão tem que prevalecer em tudo e sôbre tôdas as coisas.

\section{Bibliografia Consultada.}

Tomas M. Lindsay, Historia de la Reforma, Biblioteca de Cultura Evangélica, VIII, Edit. "La Aurora", Buenos Aires.

Émile-G. Léonard, Histoire Générale du Protestantisme, tom. I, II, Presses Universitaires de France.

L. Berkhof, The History of Christian Doctrines, Wm. B. Eerdmans Publ. Company, Michigan, I949.

Dillenberger y C. Welch, El Cristianismo Protestante, Edit. "La Aurora", Buenos Aires.

Wil. K. Anderson, Espírito e Mensagem do Protestantismo, JGEC da Igreja Metodista do Brasil, 1953.

A. N. Bertrand, El Protestantismo, Impr. Metodista, Buenos Aires, 1936.

David S. Schaff, Nossa Crença e a de nossos pais, JGEC da Igreja Metodista do Brasil, S. Paulo, 1946.

H. Sée, A. Rébillon et Ed. Préclin, Le XVIe Siècle, coleção "Clio", Presses Universitaires de France, Paris, 1950.

Henri Sée, Les Origines du capitalisme moderne, 4a ed. Paris, 1940.

Henri Hauser, Les débuts du capitalisme, Paris, 1928.

A. Dauphin-Meunier, L'Eglise en face du capitalisme, Paris, 1955.

Edwin P. Booth, Luther. Payot, Paris, 1934.

Lucien Febvre, Un Destin-Martin Luther, Presses Universitaires de France, Paris, 1952.

C. H. Irwin, Juan Calvino-Su vida y Su obra, Edic. Alba, Mexico, 1947.

JOSE' GONÇALVES SALVADOR Professor de História da Faculdade de Teologia da Igreja Metodista em São Paulo. S6cio do Instituto Histórico e Geográfico e da Sociedade de Estudos Históricos, de São Paulo. 